\title{
SOEKARNO AND SUN YAT SEN STRUGGLING FOR LIBERTY AND NATIONALISM1
}

\author{
Isbodroini Suyanto
}

\begin{abstract}
Ir Soekarno, born on June 1 ${ }^{\text {st }}$ 1091, and Dr. Sun Yat-sen, born in 1866, were unforgotten leaders until present. Soekarno was a leader determined to struggle for Indonesia's liberty since the colonial period. He felt how the people suffered those days because of the exploitation of the colonialist. His dream was to form an independent country based on nationalism. He realized that Indonesia, at that time the Dutch Indies, was plural, so he believed that nationalism based on humanity was the most appropriate, although he was strongly challenged by Islamic groups who wanted a country with Islamic principle. After independence, Pancasila became Indonesian state philosophy.

Soekarno's struggle during the colonial period was influenced by several leaders who were also struggling for freedom from exploitation, both by colonialism or the power of absolute monarchy. Several of them, such as Mahatma Gandhi, Aurobindo Ghose and Sut Yat Sen, struggled against Manchu monarchy. Sun Yat Sen's principle about nationalism, which was based on The Three Principles of the People (Sanminxhuyi) apparently influenced Soekarno in struggling for nationalism. Sun Yat Sen's struggle became reality with the birth of China Revolution in 1911
\end{abstract}

Keywords: Nationalism, Struggle for independence, Freedom, Justice

\section{Pendahuluan}

Sebelum berakhirnya Perang Dunia ke II, Ir. Soekarno dan Dr. Sun Yat Sen merupakan dua orang tokoh yang gigih memperjuangkan kebebasan bagi rakyat dari penindasan kolonialisme di Indonesia dan monarki Dinasti Manchu di Cina. Soekarno bersama dengan Moh. Hatta, dikenal sebagai Bapak Proklamator Indonesia dan Sun Yat Sen sebagai pendiri Republik Cina. Kedua tokoh tersebut bersama dengan tokoh-tokoh lainnya yang merasakan belenggu dan tekanan dari pemerintahan yang ada pada waktu itu berjuang untuk memperbaiki nasib rakyat. Perkembangan berbagai ide pemikiran yang tumbuh di Barat seperti demokrasi, nasionalisme, sosialisme, komunisme dan fasisme telah mempengaruhi tokohtokoh di luar negara-negara Barat. Dalam hal ini prinsip demokrasi yang di dalamnya antara lain terkandung nilai kebebasan dan keadilan telah mempesona tokoh-tokoh pergerakan antara lain mereka berdua, Soekarno dan Sun Yat Sen.

\footnotetext{
1 Makalah telah dipresentasikan di International Symposium, The Ideology of San Min Chu I and The Foundation of Pancasila: A Shared Vision, oleh Departemen Ilmu Politik - UI dan College of Social and Political Sciences, National Sun Yat - Sen University, ROC (Taiwan ), 31 Mei 2011, di Depok.
} 
Fokus perjuangan mereka adalah membentuk negara republik dengan faham nasionalisme atau kebangsaan. Bukan faham yang berdasarkan agama, sosialisme ataupun komunisme, meskipun faham-faham tersebut juga ikut mewarnai pemikiran mereka. Hal yang terpenting dari pemikiran mereka adalah meskipun mereka memakai konsep dari Barat, tetapi mereka meramunya dengan nilai-nilai dari akar budaya mereka masing-masing. Ini menunjukkan bahwa mereka tidak mengambil secara bulat-bulat berbagai konsep dari Barat tersebut. Hal ini tercermin dari konsep nasionalisme yang mereka kembangkan.

Faham kebangsaan atau nasionalisme yang mereka perjuangkan, sangat diwarnai oleh lingkungan kehidupan mereka yaitu nilai-nilai yang berakar dari akar sosial dan budaya mereka masing-masing. Seperti Soekano, umpamanya, nilai-nilai lokal Indonesia terutama budaya Jawa di samping nilai-nilai Barat melalui pendidikan Baratnya yang mempengaruhi gagasan-gagasannya. Konsep nasionalisme yang diramunya dengan nilai-nilai lokal dipertahankannya dengan gigih, meskipun dalam hal ini ia harus berhadapan dengan kelompok Islam. Kelompok Islam pada waktu itu antara lain adalah A.Salim, H.O.S.Tjokroaminoto, A.Hasan dan Moh. Natsir, yang menghendaki negara dengan dasar agama yaitu Islam, mengingat Islam merupakan agama mayoritas. Perwujudan konsep nasionalismenya diwujudkan Soekarno dalam Pancasila sebagai state philosophy atau dasar negara NKRI.

Dr. Sun Yat Sen yang lahir pada 1866, dikenal sebagai Bapak Republik Cina. Pada masa hidupnya, Cina berada di bawah monarki absolute dinasti Manchu. Pada masa itu Cina digambarkan sebagai negara yang miskin, selalu dilanda peperangan antara para aristokrat (warlordism) yang menambah kesengsaraan rakyat. Bencana alam seperti meluapnya sungai-sungai besar dan menghancurkan daerah-daerah pertanian juga menambah kesengsaraan rakyat. Di samping itu rakyat tidak mempunyai kebebasan dan keadilan. Hal-hal yang seperti itu telah menggerakkan beberapa orang untuk memper- baiki nasib rakyat dan membentuk pemerintahan yang tidak despotik. Diantara mereka adalah Sun Yat Sen yang mengenal pendidikan Barat. Sun Yat Sen sadar bahwa pemerintahan despotik sudah harus diakhiri kalau ingin memperbaiki nasib negara dan rakyat.

Dia mulai mengaktifkan dirinya untuk tujuan tersebut dan gerakannya dianggap bersifat revolusioner. Untuk mencanangkan gagasan-gagasannya ia mulai mencari dana ke orang-orang Cina perantauan (China living overseas) sebagai alat vital untuk mendukung gerakan revolusionernya tersebut. Dalam kerangka tersebut, ia mulai pergi ke berbagai negara. Lynn Pan mengatakan bahwa ia adalah Bapak Republik Cina yang selalu berkelana ke manca negara. Sedangkan Mao Zedong, Bapak Republik Rakyat Cina ( Father of the People's Republic) tidak pernah keluar dari Cina sampai dia berumur 56 tahun, ia hanya berkunjung ke negara Soviet Union. Sun Yat Sen pergi ke Hawai ketika ia masih berumur belasan tahun. Ia dianggap sebagai Cina's first successful international fund-raiser. ${ }^{2}$ Gerakan revolusioner Sun Yat Sen menjadi kenyataan dengan meletusnya Revolusi Cina

\footnotetext{
${ }^{2}$ Khoo Salma Nasution, Sun Yat Sen in (Penang: Areca Books: 2006) hal. 6-7.
} 
tahun 1911 yang berhasil menumbangkan kekuasaan Manchu dan Cina menjadi Republic of China.

Makalah yang singkat ini mencoba mengemukakan gerakan dari kedua tokoh tersebut dalam memperjuangkan kebebasan, keadilan dan nasionalisme bagi masyarakat mereka masing-masing. Makalah ini juga akan melihat pemikiranpemikiran Sun Yat Sen yang tertuang dalam San Min Zhuyi atau Three People's Principles yang terdiri dari Nationalism, People's Power (Democracy) and People's Livelihood. Dalam berbagai pendapatnya, Soekarno sering menyebut pemikiran-pemikran Sun Yat Sen. Ini berarti bahwa pengaruh Sun Yat Sen tak dapat dinafikan. Hasil perjuangan Soekarno tentang faham nasionalisme, kebebasan dan keadilan tertuang dalam konsep Pancasila yang terdiri dari Ketuhanan yang Maha Esa, Kemanusiaan yang Adil dan Beradab, Persatuan Indonesia, Kerakyatan yang Dipimpin oleh Hikmat Kebijaksanaan dalam Permusyawaratan dan Perwakilan, Keadilan Sosial bagi Seluruh Rakyat Indonesia. Pancasila pertama kalinya dikemukakan Soekarno pada 1 Juni 1945 di muka Badan Penyelidik Persiapan Kemerdekaan yang didirikan oleh pemerintah Jepang pada bulan Maret. Pancasila akhirnya menjadi dasar negara NKRI.

\section{Latar Belakang Sejarah Politik Ir.Soekarno}

Lahir 6 Juni 1906 merupakan tokoh yang berpengaruh di Indonesia dalam memper- juangkan kebebasan dan faham nasionalismenya. Soekarno sebagai pemuda yang terlibat dalam gerakan kebangsaan di masa penjajahan, selalu bersikap konfrontatif terhadap pemerintah Hindia Belanda. Perjuangannya menjadi sangat militan ketika ia mendirikan Partai Nasional Indonesia pada 4 Juli 1927. Ia langsung menggariskan tujuan PNI untuk meraih kemerdekaan yang disebutnya sebagai Jembatan Emas. Hal ini berbeda dengan berbagai organisasi yang bersifat kooperatif dengan kolonial pada waktu itu, meskipun organisasasi organisasi tersebut juga berjuang memperjuangkan nasib bangsa. Militansi Soekarno dalam menggerakkan rakyat, telah mengancam pemerintahan kolonial, sehingga Soekarno ditangkap pada tahun 1930 dan dipenjarakan di Sukamiskin, Bandung Partai ini akhirnya dibubarkan pada akhir April 1931. Setelah itupun Soekarno masih beberapa kali keluar masuk penjara yaitu ke Ende, di pulau Flores, dan terakhir dipenjarakan di Bengkulu.

Selama 10 tahun sebelum pendudukan Jepang, PNI seakan mati suri tetapi selama pendudukan Jepang pengaruh PNI menguat karena propaganda anti Barat yang dilan- carkan Jepang. Beberapa hari setelah kemerdekaan, bulan Agustus 1945, partai ini lahir kembali dan dimaksudkan untuk menjadi partai negara tetapi sepuluh hari kemudian partai ini dibubarkan. Setelah Wakil Presiden Moh. Hatta, mengeluarkan Maklumat No X November 1945, PNI lahir kembali besama dengan partai-partai politik baru lainnya. Partai ini merupakan wadah dari mereka yang berorientasi pada ideologi nasionalisme. Soekarno tidak bergabung dalam partai 
ini, tetapi karena ia adalah pendirinya, maka Soekarno menduduki posisi yang sangat terhormat dalam partai ini. ${ }^{3}$

\section{Soekarno dan Nasionalisme}

Pemikiran Soekarno mengenai nasionalisme yang diperjuangkannya pada masa penjajahan, mencerminkan kebenciannya terhadap kolonialisme dan imperialisme. Tidaklah mengherankan bahwa partai yang didirikannya bersifat radikal yang dengan tegas menuntut kemerdekaan. Menurut Soekarno, nasionalisme yang diperjuangkannya, berbeda dengan nasionalisme yang tumbuh di negara-negara Barat yang mengandung prinsip chauvinisme. Nasionalisme yang digagasnya bukanlah copy dari Barat seperti yang diucapkannya,

“... mengasih tempat cinta pada lain bangsa, sebagai lebar dan luasnya udara, yang mengasih tempat pada segenap sesuatu yang perlu untuk hidupnya segala hal yang hidup ... nasionalisme yang membuat kita menjadi 'perkakasnya Tuhan' dan membuat kita menjadi 'hidup dalam roh' .... ${ }^{4}$

Gerakannya dengan wadah PNI, telah menghidupkan api nasionalisme rakyat yang pada waktu itu statis dan sukar bergerak karena tekanan penjajahan, berubah menjadi dinamis. ${ }^{5}$ Soekarno berpendapat bahwa masa penjajahan merupakan masa yang mematikan dan menekan keinginan rakyat Indonesia untuk dapat mengekspresikan dirinya. Kolonialisme telah membuat bangsa Indonesia menjadi bangsa yang pasif dan seakan menyerah pada nasibnya dan seakan telah kehilangan 'roh nasionalismenya'. Untuk mengembalikan semangat yang telah hilang tersebut, semangat nasionalisme perlu diaktifkan dan dibangkitakan. Hal inilah yang mendorong Soekarno untuk memberikan semangat nasionalisme, semangat cinta bangsa.

Tidaklah dapat diingkari bahwa Soekarno mendapatkan pengaruh dari para pemimpin yang berjuang untuk membebaskan bangsanya dari penindasan. Mereka antara lain adalah Mahatma Gandhi, C.R. Das, Arabindo Ghose, Bhipin Chandra Pal, mereka dari India, Sun Yat Sen dari Cina, Mustafa Kamil dari Mesir dan Kemal Attaturk, Bapak Turki modern. Faham kebangsaan atau nasionalismenya beranjak dari definisi Ernest Renan yang mengatakan bahwa bangsa adalah "kehendak untuk bersatu" atau le desir d'etre ensemble. Sedangkan Otto Bauer mengatakan bahwa "bangsa adalah satu persatuan perangai yang timbul karena persatuan nasib". Terhadap kedua definisi tersebut, Soekarno berpendapat bahwa,

\footnotetext{
${ }^{3}$ Herbert Feith and Lance Castle (ed), Indonesia Political Thinking: 1945 - 1965 (Ithaca and London: Cornell University Press, 1970) hal. 151-152.

${ }^{4}$ Soekarno, Di Bawah Bendera Revolusi, Jilid I (Jakarta: Panitya Di Bawah Bendera Revolusi), hal. 112.

5 Soekarno, Indonesia Menggugat: Pidato Pembelaan Bung Karno di Muka Hakim Kolonial (Jakarta: Departemen Penerangan Republik Indonesia ) hal., 117.
} 
Mereka hanya memikirkan "Gemeinschaft"nya dan perasaan orangnya, ... . Mereka hanya mengingat karakter, tidak mengingat tempat tidak mengingat bumi, bumi yang didiami manusia itu. ${ }^{6}$

Soekarno dan beberapa tokoh lain berpendapat bahwa Rennan dan Bauer tidak memperhitungkan unsur tanah yaitu tempat mereka tinggal karena pada masa itu unsur geopolitik belum dianggap penting. Bumi yang dimaksud Soekarno adalah tanah yang terbentang dari Sabang sampai Merauke yang disebutnya sebagai Ibu Indonesia. Bagi seorang nasionalis ia harus mencintai Ibu Indonesia tersebut. Pandangan Soekarno yang demikian mendapatkan tantangan dari kelompok Islam yang melihat pandangan Soekarno dianggap sebagai pemujaan terhadap tanah air. Hal tersebut, bagi kelompok Islam dianggap sebagai penyembahan terhadap berhala seperti antara lain pendapat H.A. Salim. Soekarno berpendapat bahwa:

“... rasa kebangsaan yang tidak agresif, tidak serang menyerang ... I Ia bukanlah nasionalisme yang timbul dari dari kesombongan bangsa belaka; ... ia bukanlah 'jinggo nasionalisme' atau chauvinisme... . Atau haruskah nasionalismenya Mustafa Kamil, nasionalismenya Amanullah Khan, nasionalismenya Arabi Pasha, nasionalismenya Mahatma Gandhi, nasionalismenya Dr. Sun Yat Sen, nasionalismenya Aurobindo Ghose ... kita sebutkan agama yang menghambakan manusia kepada berhala 'tanah air'? ... bila itu yang dimaksud, maka kita, kaum nasionalis Indonesia dengan segala kesenangan hati bernama penyembah berhala $\ldots .{ }^{7}$

Pernyataan Soekarno tersebut menunjukkan kegigihannya dalam mempertahankan prin- sip nasionalismenya.

Soekarno menyadari bahwa untuk membangun ketangguhan nasionalisme Indonesia, berarti bahwa semua kekuatan rakyat harus menjadi satu. Hal tersebut telah dipikirkannya ketika ia menulis artikel Nasionalisme, Islamisme dan Marxisme dalam Suluh Indonesia Muda pada tahun 1926. Ia mengatakan bahwa kekuatan rakyat Indonesia ada dalam ketiga aliran tersebut dan mereka hendaknya menjadi satu. Soekarno tampaknya ingin memberi warna konsep nasionalismenya dengan merangkum semua aliran yang mewarnai masyarakat Indonesia. Prinsip nasionalisme yang berperikemanusiaan adalah memberi tempat bagi semua aliran yang ada dalam masyarakat. Dalam Demokrasi Terpimpin, penyatuan ketiga aliran tersebut menjadi kenyataan dalam bentuk Nasakom yang merupakan salah satu tiang dari Demokrasi Terpimpin. Perjuangan Soekarno akhirnya terwujud ketika Indonesia merdeka dan Pancasila dipakai sebagai dasar negara.

6 Soekarno, "Lahirnya Pancasila" dalam Tujuh Bahan Pokok Indoktrinasi (Dewan Pertimbangan Agung, 1961) hal., 28-31.

111. Soekarno, Di Bawah Bendera Revolusi. Jilid I (Jakarta: Panitya Di Bawah Bendera Revolusi), hal. 


\section{Dr. Sun Yat Sen}

Lahir pada 12 November 1866 di daerah sekitar Guangzhou, pergi ke Honolulu untuk bersekolah di sekolah Anglican Bboys School dari tahun 1879 1882. Di sini dia mulai mendapatkan pengaruh dari Barat. Tahun 1892 ia mendapat a diploma from a Hongkong Medical School dan membuka praktek di kota ini. Tahun 1983 Sun Yat Sen mulai menaruh perhatian pada politik. Ia membaca buku-buku ilmu politik dan sangat tertarik pada tulisan-tulisan Karl Marx dan karena pengaruh buku-buku politik, kemudian ia mencurahkan seluruh hidupnya pada perjuangan untuk menumbangkan Qing dynasty dan mendirikan negara republik yang stabil. Ia kembali ke Cina pada tahun 1895 dan mulai bergerak menghimpun dana dari orang-orang Cina di perantauan (overseas Chinese). Pada tahun 1905 di Jepang, ia mendirikan T'ung Meng Hui, (Chinese Revolutionary Alliance) dan menyebarkan prinsip politiknya San Min Zhuyi, yaitu Three People's Principles, yang terdiri dari nationalism, democracy dan people's livelihood. Pada tahun 1906, ia pertama kali pergi ke Penang dan mendirikan T'ung Meng Hui, dan kemudian organisasi ini didirikan di manamana sambil ia berpidato di muka publik melalui organisasi-organisasi atau berbagai perkumpulan Cina di overseas, mengenai prinsip politiknya. Antara lain di Xiao Lan Ting Club pada 1908, dia mengatakan bahwa Cina akan ditaklukan oleh negara asing apabila Manchu tidak diruntuhkan (overthrown).

Dalam gerakannya, ia selalu menyerukan bagaimana menyelamatkan Cina dari ambang keruntuhan karena kebobrokan pemerintahan Manchu yang pada waktu itu dikuasai oleh Qing dinasti. Pemerintahan Qing dianggap sebagai pemerintahan asing dari Manchu yang mendominasi etnik Han Chinese, itu sebabnya harus diruntuhkan. Pidatonya di Penang pada tahun 1907 adalah:

Ladies and gentlemen, China is now in a very dangerous position. It can be partitioned by the foreign powers at any time. But the Manchus are fearful and nervous, and are under the foreigners' control. They are willing to be the servants of the big powers, such as Britain, France, the United States, Rusia and Japan. But the Manchus oppres us ruthlessly and enslave us. Would we, the Han Chinese, not become the slaves of the slaves?... Our principle of Nationalism, one of the Three Principles, is to seek equality with the foreigners, and not to be their slaves. ${ }^{8}$

Ia selalu memberikan semangat keberanian bagi orang-orang Cina di perantauan untuk menjadi pahlawan bagi Cina. Salah seorang pengikut Sun Yat Sen, Wang Jingwei membakar semangat anti Manchu di muka orang-orang Fujian dengan pidatonya,

The main reason your ancestors migrated here was to escape persecution and enslavement by the Manchus after Zheng Chenggong's regime in Taiwan was conquered. They continued to fight to maintain their identity as the subjects of the great Ming Dynasty.

\footnotetext{
${ }^{8}$ Khoo Salma Nasution, Op. cit., hal., 28.
} 
Selanjutnya,

As your ancestors were so patriotic, how could you forget their enmity towards the Manchus? The aim of our revolutionary movement is to avenge the prosecution of our ancestors and to recover our lost nation. Our Fujian compatriots must respond fervenly to the revolutionary appeal, and help the revolution to succeed. By so doing, you will console the spirit of your ancestors in heaven. ${ }^{9}$

Demikianlah ucapan-ucapan yang membangkitkan semangat orang-orang Cina di perantauan agar mau membantu dan melibatkan diri dengan gerakan Sun Yat Sen dalam menumbangkan dinasti Manchu.

Sebelum perjuangannya berhasil, para pendukung Sun Yat Sen telah mencoba melakukan bebrapa kali pemberontakkan terhadap pemerintah yang sering mengalami kegagalan. Tetapi Sun Yat Sen selalu meyakinkan pengikutnya terutama mereka yang ada di perantauan untuk terus bergerak demi menyelamatkan negara Cina. Pemberontakan-pemberontakan tersebut antara lain pemberontakan di Zhennaguan pada Desember 1907. Ternyata pemberontakan tersebut gagal dan setelah itu, Wang Jingwei, teman Sun Yat Sen, berpidato di Penang dengan judul, "The Fujian compatriot must particulary help the Revolution". Pada bulan Februari 1910, terjadi Mutiny of the Cantonese New Army in Guangzhou. Pada 13 November 1910 Sun Yat Sen mengadakan rapat rahasia untuk mempersiapkan pemberontakan Guangzhou yang kedua dan ia mulai berkampanye untuk menghimpun dana untuk melakukan pemberontakan tersebut. Rencana tersebut terlaksana pada 27 April 1911, dilanjutkan dengan Wuchang Uprising pada 10 Oktober 1911 dan pemberontakan ini berhasil.

Ketika pemberontakan tersebut terjadi, Sun Yat Sen dikatakan bahwa ia tidak terlibat karena ia masih di pembuangan di Amerika tetapi Huang Xing yang terlibat langsung dalam revolusi tersebut. Revolusi di Wuchang tersebut telah berhasil meruntuhkan pemerintahan dinasti Manchu yang memerintah selama 2000 tahun. Sun Yat Sen segera kembali ke Cina pada 29 Desember 1911 dan dipilih sebagai provisional President of the Republic of China yang diproklamirkan pada 1 Januari 1912. Meskipun Sun Yat Sen tidak terlibat langsung dalam revolusi di Wuchang yang berhasil, tetapi ia dianggap sebagai pencetus revolusi tersebut dan yang berhasil menggugah dan memperkokoh spirit revolusi meskipun beberapa pemberontakan terhadap penguasa Manchu gagal. ${ }^{10}$ Sun Yat Sen menjadi The Father of the Republic of Cina dan juga dikenal sebagai Father of the Nation.

\section{San Min Zhuyi, Three Principles of the People}

Prinsip ini dikenal sebagai political doctrine dari Sun Yat Sen yang terdiri dari nationalism, democaracy, people's livelihood. Dr Sun Yat Sen mengeluarkan gagasan tersebut pada tahun 1905 dan hal tersebut diterbitkan pertama kalinya

\footnotetext{
99 Ibid., hal., 29

${ }^{10}$ Home > Library> Micellaneous > Wikipedia.
} 
pada tahun 1924. Selama masa perjuangannya orang menerima prinsip yang pertama, nasionalism, sebagai alat untuk menentang Manchu dynasty dan hal ini diterima oleh semua organisasi gerakan revolutioner. Dari tahun 1905 - 1925, San Min Zhuyi sebagai doktrin politik mengalami proses untuk disempurnakan. Ia menyatakan bahwa a principle is not simply an idea, it is "a faith", "a power". Nampaknya Sun Yat Sen merumuskan The Three Principles of the People, bertujuan untuk mempersiapkan Cina menghadapi pemikiran-pemikiran politik modern yang berjalan sesuai dengan perkembangan perpolitikan dunia.

Prinsip nasionalismenya adalah nationalism is above all as a racial nationalism. Nationalism haruslah berdiri atas natural forces dan ia menekankan pada unsur darah se-perti yang dikatakannya,

\section{The blood of ancesters that is "tranmitted eternally".}

Pemikirannya adalah berdasarkan pada keyakinan yang ada pada masyarakat Cina bahwa mereka, secara mistis, adalah berasal The Yellow Emperor yang mempunyai cara hidup yang sama, bahasa, agama dan adat istiadat yang sama pula. Pernyataannya yang demikian, merupakan usaha untuk menyatukan masyarakat Cina yang berada di perantauan. Dalam hal ini Sun Yat Sen tidak memasukkan unsur teritori seperti pendapat Soekarno, Lenin dan Stalin. Dalam negara modern, sebuah bangsa dapat terdiri dari bermacam ras tetapi Sun Yat Sen berkata bahwa, "China has been developing a single state out of a single race". Dalam hal ini ia berpendapat bahwa memang terdapat bermacam ras atau etnik di Cina tetapi telah terjadi asimilasi kultural untuk mempersatukan bangsa Han. Nasionalisme Cina juga tidak boleh melupakan nilai-nilai Confusian virtue yaitu, mengasihi, kesetiaan dan perikemanusiaan atau humanity. Dengan berdiri atas moral Cunfusian dan asimilasi dari berbagai ras dan etnik, Cina di hari depan akan menjadi sebuah bangsa besar yang bersatu - The Republic of China. ${ }^{11}$

Dasar pemikiran nasionalismenya yang lain adalah, dulu melawan Manchu dynasty tetapi sekarang adalah mengakhiri intervensi imperialisme asing di Cina. Pada waktu itu terdapat hak-hak dan status istimewa orang Barat dan Jepang yang memiliki perusahaan-perusahaan di samping terdapatnya penetrasi ekonomi asing di Cina. Pada masa itu terdapat berbagai negara dari Barat, Jepang dan Soviet yang melakukan kegiatan perdagangan sehingga Sun Yat Sen menggambarkan Cina sebagai "a colony of powers". Sun Yat Sen selalu menyerukan unity. Itu sebabnya menkipun ia mengagumi Marx dan mempunyai hubungan yang dekat dengan Soviet, tetapi ia menolak the class contradiction at the heart of the revolution. Unity dengan dasar tradisi diperlukan untuk dapat menciptakan a social consensus and social harmony yang dianggap penting. Tradisi yang dimaksudkannya adalah Confusian moral values, such as loyalty, filial piety, and humanity. Nasionalisme yang dikonstruknya adalah merupakan synthesa antara modern nasionalism and traditional humanism. Hal ini akan mengarah kepada cultural ethnocentrism seperti yang telah ditanamkan dalam dalam budaya Cina. ${ }^{12}$

\footnotetext{
${ }^{11}$ Marie - Claire Bergere, Sun Yat Sen (Stanford, California: Stanford University Press, 1998) hal., 356-559.

12 Ibid., hal., $361-370$.
} 


\section{The Rights of the People, an Instrument of Democracy}

Pada tahun 1905, Sun Yat Sen menjelaskan pemikirannya dalam T'ung Meng Hui atau Chinese Revolutionary Alliance, tentang demokrasi dan ia sempat berpikir untuk sebuah demokrasi konstitusional. Ide kebebasan dari Barat yang telah merasuki para mahasiswa yang menghendaki revolusi Cina hendaknya meniru seperti di Barat. Tetapi Sun Yat Sen berpendapat Cina mempunyai caranya sendiri dalam berrevolusi. Cina harus berjuang di jalannya sendiri untuk mencapai true liberty for the people. Dia menolak individualisme yang merupakan dasar nilai dari demokrasi di Barat dalam kaitan hubungan Negara dan individu. Sun Yat Sen mendorong kesatuan dari perspektif tradisional. Tujuannya yang utama adalah memperkuat bangsa atau the nation, di mana Cina memerlukan suatu pemerintahan kesatuan yang kuat dan bersifat centralized. Prinsip liberty adalah the power of the nation. ${ }^{13}$

Sun Yat Sen berpendapat mengenai kekuasaan rakyat dalam demokrasi adalah,

"The majority of the people are without vision. We who have prevision must lead them into the right way".

Ini berarti bahwa kedaulatan rakyat bergantung pada segelintir (minority) orang yang akan menuntun rakyat menuju demokrasi. Minoritas yang memimpin adalah mereka yang dipilih rakyat. Ia menekankan bahwa rakyat mempunyai hak-hak rakyat atau people's rights antara lain adalah hak memilih atau people's sufferage. Jadi pemimpin tidak akan melakukan abuse of power terhadap rakyat. Dalam kaitan antara rakyat dan pemerintah, ia membedakan dua kekuasaan yaitu the power of the people and the power of the government. Rakyat berdaulat tetapi tidak menjalankan kekuasaan. Dalam demokrasi Barat melekat trias politika yaitu the eksekutif, legislatif dan yudikatif. Sun Yat Sen menambahkan prinsip tersebut dengan $a$ power of examination and a power of censure. Kedua prinsip tersebut berasal dari tradisi imperium Mandarin dalam kerangka merekrut seseorang dan menempatkan orang tersebut tetap dalam pengawasan. Lima kekuasaan ini merupakan landasan untuk konstitusi yang akan menjadi mesin penggerak pemerintahan. Bagaimanapun besarnya kekuasaan pemerintah tetapi pemerintahan berada di bawah kontrol rakyat. ${ }^{14}$ Dalam demokrasi, hal ini dikenal dengan kedaulatan rakyat yang diakui oleh Sun Yat Sen dan ia mengatakan bahwa kedaulatan rakyat bersandar pada (rest upon) 4 kekuasaan yaitu memilih (suffrage), menarik dukungan (revocation), berinisiatif (initiative) dan referendum. Dia mengatakan bahwa,

"the foundation of the government of a nation must be build upon the rights of the people, but the administration of government must be

13 Ibid., hal., $370-374$.

14 Ibid., hal., 376 
entrust to experts" and the incompatibility between democracy and efficiency would be wiped out. ${ }^{15}$

Jadi negara haruslah didirikan atas hak rakyat tetapi administrasi negara atau jalannya pemerintahan haruslah dilakukan oleh para ahli atau para birokrat yang berpengalaman. Dengan demikian maka tak akan tedapat lagi masalah yang ditimbulkan karena antara demokrasi dan kelambanan jalannya pemerintahan. Dia yakin bahwa dengan the five powers dan doktrin tentang kedaulatan rakyat yang diramu dengan nilai-nilai traditional, China akan menjadi negara demokrasi yang maju.

\section{The Principle of the Livelihood of the People}

Dalam perkembangan pemikirannya, Sun Yat Sen memberikan perhatian yang besar pada "masalah sosial". Dia mengatakan bahwa,

"The problem of livelihood is the problem of subsistence ... . Livelyhood is the central force in social progress ... and social progress is the central force in history"

Tampaknya pernyataannya tersebut mendapat pengaruh dari Marx tentang perkembangan sejarah manusia, materialisme sejarah. Tetapi Sun Yat Sen menolak pendapat Marx yang menekankan bahwa unsur materi yang membawa perubahan bagi sejarah manusia yang dipenuhi dengan konflik-konflik kelas. Sun Yat Sen menyatakan bahwa

"The principle force in human evolution is cooperation, not conflict. If society makes progress, that can only be because of the harmony between the economic interest of society multitudes" 16

Dalam pemikirannya, ia selalu berusaha bagaimana menciptakan harmony bukan konflik, sebagai nilai yang utama dalam confusianism. Itu sebabnya ia menolak perjuangan kelas dan tentang kapitalisme. Sun Yat Sen berpendapat membatasi kapitalisme, bukan menumbangkannya. Hal ini berbeda dengan Marx yang bertujuan untuk menumbangkan kapitalisme yang menyebabkan kemiskinan. Ia menyadari bahwa Cina berada dalam kemiskinan dan hal tersebut bukan karena distribusi kemakmuran yang timpang tetapi karena para petani dimiskinkan oleh para tuan tanah yang melahirkan ketidak adilan yang terjadi dimana-mana. Untuk mengatasi hal tersebut adalah berikanlah tanah kepada para petani, berikanlah tanah pada mereka yang mengolahnya. ${ }^{17}$ Pendapatnya bertentangan dengan teman-teman komunisnya (communist allies) yang berpendapat bahwa petani harus melakukan perubahan secara revolusioner (agrarian radicalism). Dalam hal ini Sun Yat Sen menghendki perubahan yang bertahap, agar harmoni tidak terganggu. Di samping itu untuk mengentaskan kemiskinan, industrialisasi harus dilakukan dan negara yang mengendalikan dan mengawasinya. Hal ini untuk mencegah agar

\footnotetext{
15 Ibid., hal., $376-377$.

16 Ibid., hal., 384 .

17 Ibid., hal., 387-388
} 
tidak terjadi penumpukan kekayaan di satu kelompok saja (a wealthy class) yang akan melahirkan ketidak setaraan dalam masyarakat. Terhadap masuknya pengusaha-pengusaha asing, ia berpendapat bahwa kerjasama dengan negrara asing hendaknya didasarkan pada persamaan kedudukan. ${ }^{18}$

Dari uraian secara singkat tentang prinsip Sun Yat Sen's Sun Min Zhuyi atau Three Principles of the People, kita dapat menarik kesimpulan bahwa ia sangat terbeban untuk mengatasi kemiskinan dan keterbelakangan rakyat Cina. Dinasti Manchu tidak berusaha untuk menanggulangi hal tersebut, bahkan menambah kesengsaraan rakyat karena perebutan kekuasaan antar para landlords. Pendidikan dan kontak-kontaknya dengan negara-negara Barat seperti Soviet, Jerman, Perancis, Inggris, Amerika ${ }^{19}$ telah melahirkan pemikirannya tentang nasionalisme, demokrasi, kebebasan dan kesejahteraan. Konsep-konsep tersebut diramunya dengan nilai-nilai, etika dan moral Confusianism yang bertumpu pada harmoni dan kemanusiaan, telah melahirkan Sun Min Zhuyi atau Three Principles of the People. Dia yakin bahwa dengan Sun Min Zhuyi, Cina dapat menjadi negara yang besar dan kuat untuk memasuki dunia yang modern.

\section{SOEKARNO and PANCASILA (FIVE PRINCIPLES)}

Pancasila diucapkan Soekarno pertama kali pada 1 Juni 1945 di Badan Penyelidik Persiapan Kemerdekaan (Investigating Committee for the Preparation ofIndependence). Badan tersebut didirikan oleh Jepang pada bulan Maret 1945. Lima Prinsip tersebut adalah nationalisme, internasionalisme, demokrasi, keadilan sosial dan percaya kepada Tuhan. ${ }^{20}$ Prinsip-prinsip tersebut adalah hasil pergulatan pemikirannya di masa sebelum kemerdekaan. Dalam kerangka mencari ideologi negara dan konstitusi, dibentuklah sebuah panitia dalam BPPK pada tanggal 22 Juni 1945 yang terdiri atas 9 orang dengan ketua Soekarno dan Hatta, untuk mengkompromikan masalah Piagam Jakarta. BPPK menyetujui Pancasila dengan beberapa modifikasi yaitu prinsip terakhir dalam pidato Soekarno yaitu percaya kepada kepada Tuhan agar dijadikan sebagai prinsip pertama dengan mencantumkan Piagam Jakarta yaitu, Percaya kepada Tuhan dengan keharusan menjalankan syariat Islam bagi para pemeluknya. Prinsip percaya kepada Tuhan disetujui sebagai prinsip yang pertama tetapi kalimat "dengan keharusan menjalankan syariah Islam bagi para pemeluknya", tidak disetujui oleh nonMuslim. ${ }^{21}$

Setelah perubahan tersebut, rumusan Pancasila menjadi prinsip yang pertama adalah Ketuhanan yang Maha Esa, prinsip kedua, Kemanusiaan yang Adil dan Beradab, Perikemanusiaan, prinsip yang ketiga; keempat adalah

\footnotetext{
${ }^{18}$ Ibid., hal., 388-391.

19 Harold C. Hinton, "Cina" in George McT. Kahin (ed), Major Governments of Asia,(Ithaca,New York: Cornell University Press: 1963) hal $15-17$.

20 Herbert Feith \& Lance Castles,ed.,Indonesia Political Thinking, 1945 -1965 (Ithaca and London: Cornell University Press, 1970) hal $40-49$.

21 Leo Suryadinata, "National Ideology and Nation-Building in Multi -Ethnic States: Lessons from Other Countries in John S.T. Quah, In Search of Singapore's National Values (Singapore, Institute of policy Studies, Times Academic Press, 1990) hal. 24 -26.
} 
Kerakyatan yang Dipimpin oleh Hikmat Kebijaksanaan dalam Permusyawaratan dan Perwakilan, dan prinsip terakhir adalah Keadilan Sosial bagi Seluruh Rakyat Indonesia. Pancasila akhirnya diterima sebagai ideologi Negara dan tercantum dalam Preambul Undang-Undang Dasar 1945. ${ }^{2}$

Soekarno yang dibesarkan terutama dalam lingkungan budaya Jawa menyerap nilai-nilai inti dari budaya tersebut yaitu keseimbangan, keselarasan dan keharmonisan yang bermuara pada menciptakan hidup dalam harmoni. Nilainilai tersebut adalah perwujudan dari sinkretisme budaya Jawa yang melahirkan sifat yang akomodatif ${ }^{23}$. Dia juga bersentuhan dengan dunia Barat melalui pendidikannya sampai ke Institut Teknologi Bandung. Berbagai konsep Barat modern seperti demokrasi, nasionalisme, sosialisme dan komunisme, bangsa, liberty, equality dan semacam itu digelutinya melalui buku-buku pengetahuan Barat.

. Ia bersama dengan tokoh-tokoh pergerakan dengan ideologi, agama dan etnik yang beragam, bersama-sama bergulat dengan tujuan yang sama yaitu bagaimana menyatukan rakyat yang terbelah-belah dalam satu wadah kebangsaan atau nasionalisme. Tidaklah dapat dipungkiri bahwa Soekarno telah dipengaruhi oleh berbagai pergerakan yang terjadi di berbagai negara jajahan yang bertujuan untuk melepaskan diri dari penindasan kolonial dengan kemiskinan sebagai akibatnya. Pergulatan pemikiran dan politiknya, nilai-nilai budaya bangsanya dan persentuhannya dengan pengetahuan Barat modern telah mengkristal dalam prinsip Pancasila. Uraian di bawah ini mengemukakan prinsip-prinsip Pancasila yang diucapkannya pada 1 Juni 1945.

\section{Prinsip Pertama, Nasionalisme}

Faham nasionalisme yang dikembangkan oleh Ernest Renan dan Otto Bauer dianggapnya sudah tidak cocok. Soekarno dalam hal ini memasukkan unsur teritori, jadi nation Indonesia adalah daerah, pulau-pulau yang terbentang dari Sabang sampai Merauke. Rakyat hidup di atas tanah tersebut dan diikat oleh prinsip nasionalisme yang berdiri di atas prinsip kemanusiaan, "My nationalism is humanity". Kata-kata tersebut diucapkan oleh Mahatma Gandhi yang mengatakan, ..."Saya seorang nasionalis, tetapi kebangsaan saya adalah peri kemanusiaan". Soekarno menekankan nasionalisme Indonesia bukan bersifat chavinistis. Dalam hal ini, Soekarno berbeda dengan Sun Yat Sen yang mengatakan bahwa nasionalisme Cina berdasarkan pada prinsip darah yaitu, "The blood of ancestors that is transmitted eternally". Sun Yat Sen tidak memasukkan unsur teritori seperti Soekarno yang menganggap unsur tersebut sangat penting, sama seperti pandangan Lenin dan Stalin.

\section{Prinsip kedua, Internasionalisme}

${ }^{22}$ Herbert Feith \& Lance Castle, ed, Op.cit.

${ }^{23}$ Bernhard Dahm, Sukarno and the Struggle for Indonesia Independence (Ithaca and London: Cornell University Press, 1968). Dahm menguraikan sosialisasi kehidupan Soekarno. 
Internasionalisme yang dimaksudkannya bukanlah sama dengan kosmopolitanisme tetapi ia ingin menekankan bahwa setelah PD II berakhir, hubungan antar bangsa-bangsa bersifat sama, sejajar. Itu sebabnya harus ada hubungan yang harmonis antar negara-negara pasca colonial (post colonial countries) dengan negara-negara Barat dalam kerangka kehidupan internasional. Di sini Soekarno tampaknya mau menghapus kebenciannya pada negara-negara Barat yang telah mengeksploitasi negara-negara jajahan dan yang telah melahirkan kemiskinan dan keterbelakangan. Bukan lagi saatnya memusuhi mereka dan hal ini adalah cermin dari prinsipnya "my nationalism is humanity". Pernyatannya,

Internationalisme tidak dapat hidup subur, kalau ia tidak berakar di buminya nasionalisme. Nasionalisme tidak dapat hidup subur apabila ia tidak berada dalam taman bunganya internasionalisme. Kedua prinsip tersebut saling bertaut satu dengan lainnya. ${ }^{24}$

Pendapatnya tersebut didasarkan pada telah terjadinya perubahan setelah berakhirnya PD II, di mana kedudukan semua bangsa adalah sama setelah dilahirkannya The Declaration of Human Rights oleh PBB. Tidak terdapat lagi perbedaan tinggi dan rendah antar bangsa-bangsa di dunia.

\section{Prinsip ketiga, Mufakat, Perwakilan, Permusyawaratan}

Menurut Soekarno, Indonesia bukan negara untuk satu golongan saja, walaupun golongan kaya. Ketiga prinsip tersebut adalah, mencerminkan nilai-nilai budaya masyarakat Indonesia yang menyelesaikan setiap masalah dengan cara bermusyawarah untuk mencapai mufakat ${ }^{25}$. Soekarno juga sangat menyadari bahwa Indonesia adalah negara yang sangat plural, sehingga dalam nation state Indonesia semua harus dirangkul. Dia menekankan bahwa, we shall set up a state of "all for all", one for all, all for one". Dia menekankan kekuatan nation Indonesia adalah permusyawaratan atau deliberation among reperesentatives. Prinsip tersebut merupakan landasan bagi demokrasi Indonesia Tampaknya ia tidak setuju dengan demokrasi Barat yang memakai prinsip mayoritas dan minoritas. Badan perwakilan yang merupakan kekuasaan rakyat disetujuinya tetapi dengan mekanisme permusyawaratan. Soekarno memandang bahwa masyarakat Indonesia merupakan satu keluarga yang selalu bermusyawarah dalam mengambil suatu keputusan.

Bagi Sun Yat Sen, demokrasi bersifat elitis karena ia menekankan bahwa "yang mayoritas tidak mempunyai visi" ("the majority of the people are without vision"), sehingga orang yang mempunyai prevision, yaitu kelompok minoritas atau elit haruslah memimpin mayoritas. Terdapat perbedaan antara kekuasaan rakyat dan kekuasaan pemerintah. (There is a distinction between the power of the people and the power of government). Rakyat berdaulat tetapi mereka tidak menjalankan kekuasaan pemerintah. Meskipun demokrasinya bersifat elitis tetapi rakyatlah

\footnotetext{
${ }^{24}$ Ibid., hal., 44.

25 Ibid., hal., 44.
} 
yang berkuasa, ... "the people are masters of the nation ... however powerful, the government must under the control of the people".

Antara Sun Yat Send dan Soekarno terdapat persamaan dalam prinsip kedaulatan rakyat. Tetapi Sun Yat Sen tidak begitu menjelaskan bagaimana hubungan rakyat dan pemerintah bila terdapat hal-hal yang berbeda antara keduanya. Sun Yat Sen menekan- kan pada pemerintahan yang kuat. Tampaknya ia menyetujui apa yang telah dilakukan oleh para petinggi pemerintahan imperium yaitu "a unified and centralized government". Sedangkan Soekarno, meskipun ia menekankan pada persatuan tetapi semua dilandasi pada prinsip musyawarah dan mufakat.

\section{Prinsip keempat adalah Kesejahteraan}

Prinsip kesejahteraan dalam pandangan Soekarno tak dapat dicapai dengan demokrasi Barat karena demokrasi Barat sebagai hasil dari revolusi Perancis, hanya menitik beratkan pada political democracy atau politieke democratie. Di sini tidak ada keadilan. Dia mengambil contoh bahwa kaum buruh dapat menjatuhkan seorang menteri, tetapi besoknya si buruh dapat dipecat, dia akan kehilangan pekerjaan dan tidak bisa makan. Soekarno menggambarkan ketimpangan akan terjadi dengan prinsip demokrasi Barat sepperti yang dikatakannya,

Bukan demokrasi Barat, tetapi permusyawaratan yang memberi hidup, yakni politiek-economieshe democratie yang mampu mendatangkan kesejahteraan social. ${ }^{26}$

Jadi demokrasi politik saja tidak akan dapat mengentaskan kemiskinan dan tidak akan dapat menciptakan keadilan social. Demokrasi politik, menurut Soekarno, tidak dapat meraih rakyat sampai ke grassroot, yaitu buruh dan petani untuk memperbaiki nasib mereka.

Pemikiran Soekarno untuk menciptakan social justice atau kemakmuran bagi rakyat tidak berbeda dengan Sun Yat Sen yang mengatakan bahwa kemiskinan dapat dientaskan dengan memberikan hak pada para petani. Para petani pada waktu itu mengalami eksploitasi atas tanah pertanian mereka oleh para tuan tanah. Sun Yat Sen menekankan, "biarkanlah tanah menjadi milik mereka yang mengerjakan tanah tersebut". Pemberian hak penuh pada petani akan dapat memperbaiki kemiskinan dari para petani. Ia juga menganjurkan industrialisasi dengan menggunakan mesin-mesin dalam berproduksi untuk meningkatkan taraf hidup rakyat.

\section{Prinsip kelima, Percaya kepada Tuhan.}

Soekarno mengetahui bahwa Islam merupakan agama yang dianut oleh mayoritas, tetapi ia juga menyadari bahwa di Indonesia juga terdapat agamaagama lain yang harus pula mendapatkan tempat yang sama. Itu sebabnya dia berkata "setiap orang Indonesia hendaknya percaya kepada Tuhannya masing-

\footnotetext{
26 Ibid., hal. 46-47.
} 
masing". Biarlah masing-masing agama hidup berdampingan denagan cara yang beradab", yaitu saling menghormati, dan saling bertoleransi seperti yang pernah dilakukan oleh Nabi Mohammad and Jesus Kristus. Kata-kata "Tuhannya sendiri" ("his own God)," menunjukkan bahwa setiap orang Indonesia mempunyai kebebasan dalam memeluk agamanya masing-masing tanpa dilandasi oleh egoisme agama. ${ }^{27}$

\section{Gotong Royong}

Lima prinsip Pancasila oleh Soekarno diperas menjadi socio-nasionalisme untuk nasionalisme dan internasionalisme, nasionalisme dan kemanusiaan. Demokrasi yang berlandaskan pada permusyawaratan dan kesejahteraan, juga diperas menjadi sosio-demokrasi, sehingga, kelima prinsip tersebut menjadi menjadi sosio-nasionalisme, sosio-demokrasi, dan percaya kepada Tuhan diperas sehingga menjadi satu dan melahirkan prinsip Gotong Royong. Gotong Royong, menurut Soekarno, merupakan landasan yang hebat (marvelous) bagi negara Indonesia. Prinsip gotong royong dan kekeluargaan merupakan nilai yang dianut oleh masyarakat Indonesia. Gotong royong menggambarkan kedinamisan daripada kekeluargaan. Keluarga-keluarga bekerjasama, bergotong royong dalam melakukan sesuatu. Dalam bergotong royong, orang tidak memandang status seseorang, agama, etnik, ras ataupun asal orang tersebut. Negara atas prinsip gotong royong itulah yang didambakan Soekarno.

\section{Kesimpulan}

Terdapat kemiripan antara Dr Sun Yat Sen dan Ir Soekarno dalam menuangkan pemikiran mereka untuk memperbaiki dan membangun masyarakat dari kedua orang tokoh tersebut. Meskipun kedua tokoh tersebut mendapatkan pengaruh dari Barat, tetapi dalam pemikiran mereka tentang masyarakat dan negara, mereka tidak menerima prinsip-prinsip Barat secara bulat-bulat. Pemikiran Sun Yat Sen yang tertuang dalam San Ming Zhuyi, Three Principles of the People diwarnai oleh nilai-nilai moral dan etika Confusianism seperti loyalty, filial piety and humanity, serta menekankan pada keselarasan dan keharmonisan. Unity dengan dasar tradisi untuk mencapai konsensus dan harmoni sosial adalah penting. Sun Yat Sen meyakini bahwa perubahan dalam masyarakat dengan berpegang pada prinsip San Ming Zhuyi dan nilai-nilai Confusianism akan dapat membawa China menjadi negara modern, the Republic of China. Sampai sekarang San Min Chu I tetap dihayati dan hidup sebagai ideologi negara Taiwan.

Begitu pula halnya dengan Soekarno, rumusan Pancasila-nya sangat sarat diwarnai oleh nilai-nilai yang dianut masyarakat. Ia menyadari bahwa masyarakat Indonesia sangat plural dengan berbagai nilai dan adat kebiasaan, harus dirangkul. Itu sebabnya, meskipun ia menerima demokrasi Barat tetapi ia 
tidak menggunakan prinsip mayoritas dan minoritas. Ia memilih "all for all", "one for all", "all for one", yaitu "semua untuk semua, satu untuk semua, semua untuk satu" Mekanisme politik negara dan pemerintahan hendaknya berdiri atas prinsip mufakat, atas permusyawaratan-perwakilan. Dan di atas semuanya prinsip gotong royong hendaknya mewarnai kehidupan negara. Negara Republik Indonesia adalah Negara Gotong Royong. Setelah butir-butir Pancasila seperti yang dikemukakan di atas melalui beberapa modifikasi oleh BPPK, Pancasila menjadi ideologi negara yang diproklamirkan pada 17 August 1945.

Catatan yang perlu diperhatikan ialah, bila kita akan menjadikan Pancasila sebagai ideologi negara yang mantap dan kokoh sebagai pandangan hidup bangsa Indonesia, kita perlu melakukan sosialisasi yang terus menerus serta bagaimana menerapkan nilai-nilai Pancasila tersebut dalam masyarakat.

\section{Daftar Pustaka}

Bergere, Marie-Claire. 1998. Sun Yat Sen. Stanford, California: Stanford University Press.

Dahm, Bernhard. 1968. Sukarno and the Struggle for Indonesia Independence. Ithaca and London: Cornell University Press.

Feith, Herbeth dan Lance Castles (Ed). 1970. Indonesia Political Thinking, 1945-1965. Ithaca and London: Cornell University Press.

Hinton, Harold C. 1963. "China" dalam George McT. Kahin (ed), Major Governments of Asia. Ithaca, New York: Cornell University Press.

Nasution, Khoo Salam. 2006. Sun Yat Sen in Penang. Penang: Areca Books

Soekarno. Indonesia Menggugat: Pidato Pembelaan Bung Karno di Muka Hakim Kolonial. Jakarta: Departemen Penerangan Republik Indonesia. Tanpa Tahun

Soekarno. 1961. “Lahirnya Pancasila” dalam Tujuh Bahan Pokok Indoktrinasi. Jakarta: Dewan Pertimbangan Agung.

Soekarno. 1964. Di Bawah Bendera Revolusi. Jilid I. Jakarta: Panitya Penerbit Di Bawah Bendera Revolusi

Suryadinata, Leo. 1990. "National Ideology and Nation-Building in Multi-Ethnic States: Lessons from Other Countries" dalam John S.T. Quah. In Search of Singapore's National Values. Singapore: Institute of Policy Studies. Times Academic Press. 